\title{
LATERAL MOVEMENT OF CONTAMINATED GROUND WATER FROM MERRILL FIELD LANDFILL, ANCHORAGE, ALASKA
}

by Jilann O. Brunett

U. S. GEOLOGICAL SURVEY

Open-File Report 89-624

Prepared in cooperation with the

MUNICIPALITY OF ANCHORAGE

Anchorage, Alaska

1990 


\section{DEPARTMENT OF THE INTERIOR}

MANUEL LUJAN, JR., Secretary

\section{U.S. GEOLOGICAL SURVEY}

Dallas L. Peck, Director

For additional information write to:

District Chief

U.S. Geological Survey Water Resources Division 4230 University Dr., Suite 201 Anchorage, Alaska 99508-4664
Copies of this report can be purchased from:

U.S. Geological Survey

Books and Open-File Reports Section

Federal Center, Bldg. 810

Box 25425

Denver, Colorado 80225 


\section{CONTENTS}

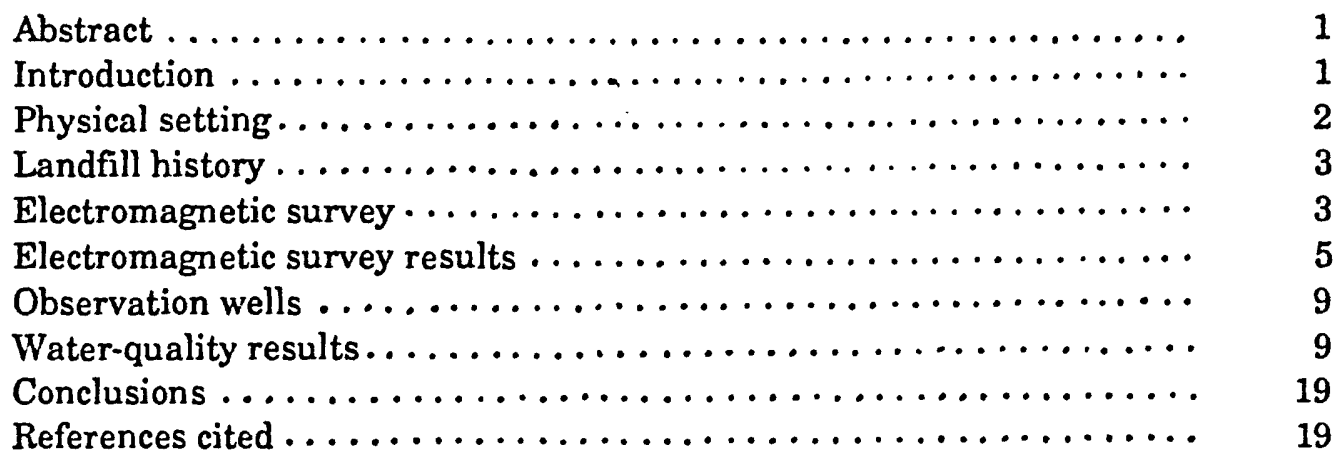

\section{ILLUSTRATIONS}

Figure 1. Map showing location of Merrill Field landfill in Anchorage . . . . . . . 2

2. Diagram showing generalized stratigraphic column........... 3 Maps showing:

3. Background values, apparent earth conductivity, in millisiemens

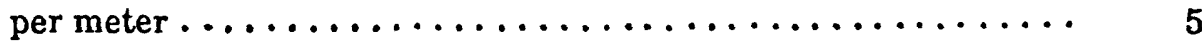

4. Apparent earth conductivity, 10 -meter coil spacing ........... 6

5. Apparent earth conductivity, 20 -meter coil spacing ........... 7

6. Apparent earth conductivity, 40 -meter coil spacing .......... 8

7. Locations of observation wells, and geologic section through the wetlands and the landfill ....................... 11

8. Location of wells 13-22 sited in areas of high earth conductivity .... 12

9. Graph showing relation between earth conductivity and specific conductance of ground water ................... 13

10. Graph showing changes in specific conductance, concentration of chloride, and number of organic pollutants detected in each well with increasing distance from the landfill.

(1)

5

6

8

1

12

\section{TABLES}

Table 1. Approximate exploration depths for EM34-3 at various intercoil spacings 4

2. Observation well information ..................... 10

3. Chemicals detected in ground-water samples ................ 14

4. Chemicals analyzed but not detected in any samples ............ 15

5. Wells in which concentrations exceeded drinking-water standards ..... 16

6. Selected chemical constituents of North Fork Chester Creek above and below the landfill ......................... 18 


\section{CONVERSION FACTORS AND ABBREVIATIONS}

For readers who may prefer to use metric (International System) units rather than inch-pound units, the conversion factors for the terms used in this report are listed below:

Multiply inch-pound unit

foot $(\mathrm{ft})$

mile (mi)

acre

gallon per minute (gal/min)

degree Fahrenheit $\left({ }^{\circ} \mathrm{F}\right)$
By

0.3048

1.609

0.4047

0.06308

${ }^{\circ} \mathrm{C}=5 / 9 \times\left({ }^{\circ} \mathrm{F}-32\right)$
To obtain metric unit

meter $(\mathrm{m})$

kilometer $(\mathrm{km})$

hectare

liter per second $(\mathrm{L} / \mathrm{s})$

degree Celsius $\left({ }^{\circ} \mathrm{C}\right)$

Other abbreviations in this report are:

$\mathrm{mg} / \mathrm{L}$, milligrams per liter

$\mu \mathrm{g} / \mathrm{L}$, micrograms per liter

$\mathrm{mS} / \mathrm{m}$, millisiemens per meter

\section{ALTITUDE DATUM}

\section{Sea level:}

In this report "sea level" refers to the National Geodetic Vertical Datum of 1929 (NGVD of 1929)-- a geodetic datum derived from a general adjustment of the first-order level nets of both the United States and Canada, formerly called Sea Level Datum of 1929. 


\title{
LATERAL MOVEMENT OF CONTAMINATED GROUND WATER FROM
}

MERRILL FIELD LANDFIL, ANCHORAGE, ALASKA

By Jilann O. Brunett

\begin{abstract}
A sanitary landfill used in Anchorage, Alaska, since the 1940's was closed in 1987. Leachate from the landfill does not appear to be contaminating a small creek flowing through a conduit in the landfill, but-leachate is being transported by ground water into a wetlands to the south. An electromagnetic survey of the unconfined aquifer and subsequent sampling from wells indicate that minor amounts of contaminants have reached much of the wetlands as far as Chester Creek, about 2,200 feet to the south. However, concentrations of these contaminants in the ground water are generally less than U.S. Environmental Protection Agency standards for drinking water except within the landfill itself.
\end{abstract}

\section{INTRODUCTION}

The Merrill Field solid-waste landfill (fig. 1) was used for refuse disposal since the 1940's. When the site was closed in 1987, approximately 200 acres had been covered with soil and refuse to an average thickness of about $30 \mathrm{ft}$. Some of the refuse has been buried below the water table, thereby creating an environment in which the refuse is continuously leached.

Nelson (1982) analyzed vertical movement of ground water and determined that minor amounts of pollutants may reach the upper confined aquifer after many tens of years, but that water of the composition of leachate may not reach the upper confined aquifer for more than three centuries. However, his study did not address lateral migration of contaminants in the shallow unconfined aquifer.

The purpose of this study was to determine the extent of contamination of the shallow unconfined aquifer downgradient from the landfill. Ground water under the landfill was thought to move in the direction of the topographic gradient, toward Chester Creek. The wetlands between the landfill and Chester Creek therefore became the primary focus of this investigation.

The U.S. Geological Survey did this study in cooperation with the Municipality of Anchorage. The Municipality drilled the test wells and provided information on subsurface materials in the study area, as well as information on the history of the landfill. 


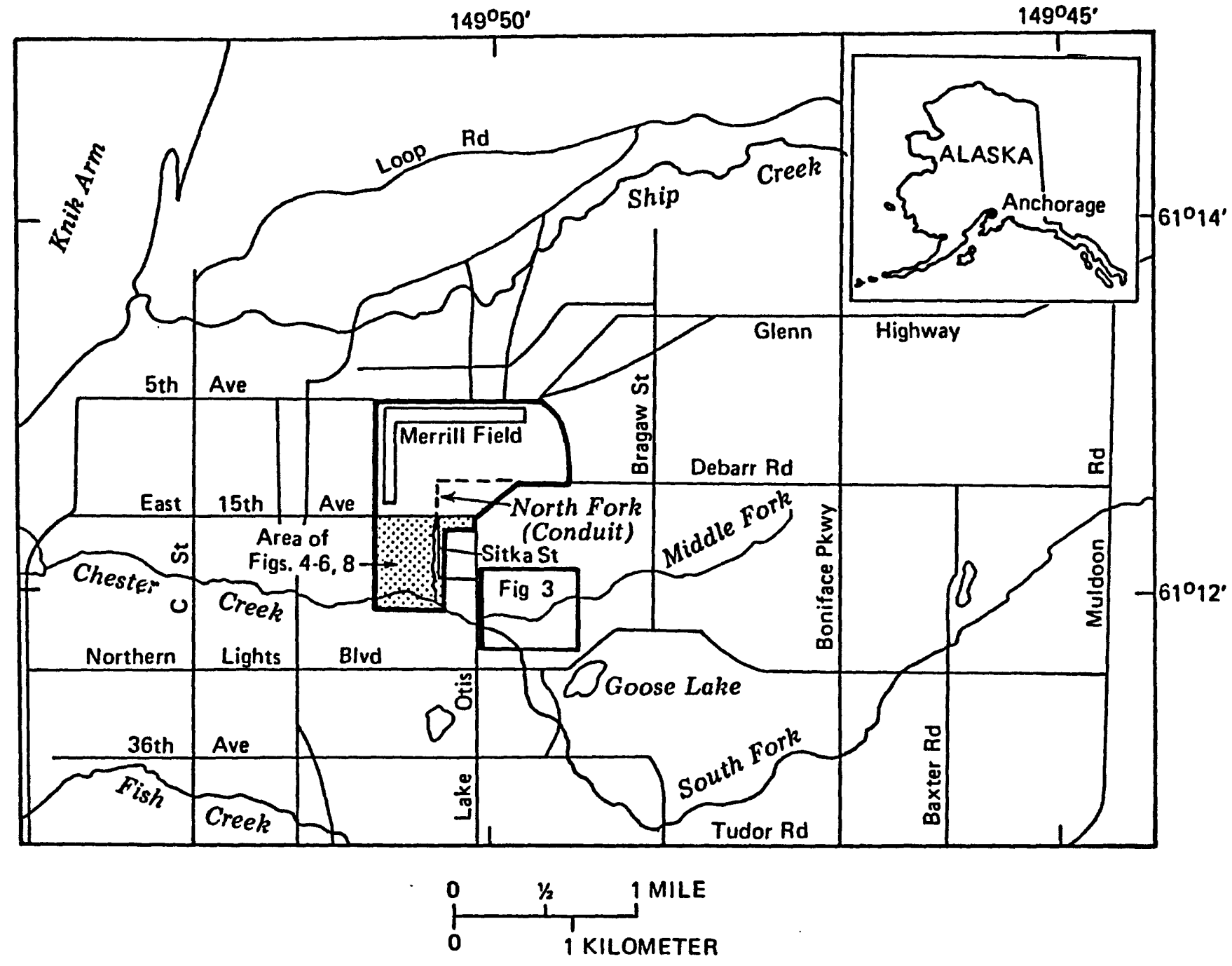

Figure 1.--Location of Merrill Field landfill in Anchorage.

\section{PHYSICAL SETTING}

In the 1940's Merrill Field Airport was on the outskirts of Anchorage. To the east and south of the airport was a high bluff overlooking the North Fork Chester Creek valley. This valley was from 1,300 to $2,600 \mathrm{ft}$ wide in most places, and was wet and marshy.

The study area is underlain by a complex sequence of stratified glacial, fluvial, and lacustrine sediments, which Nelson (1982) generalized into seven units (fig. 2). The uppermost unit is an unconfined aquifer that consists of silty sand and gravel. In the wetlands the unconfined aquifer is generally less than $30 \mathrm{ft}$ thick and is underlain by a poorly permeable silty clay that inhibits the vertical movement of water. 


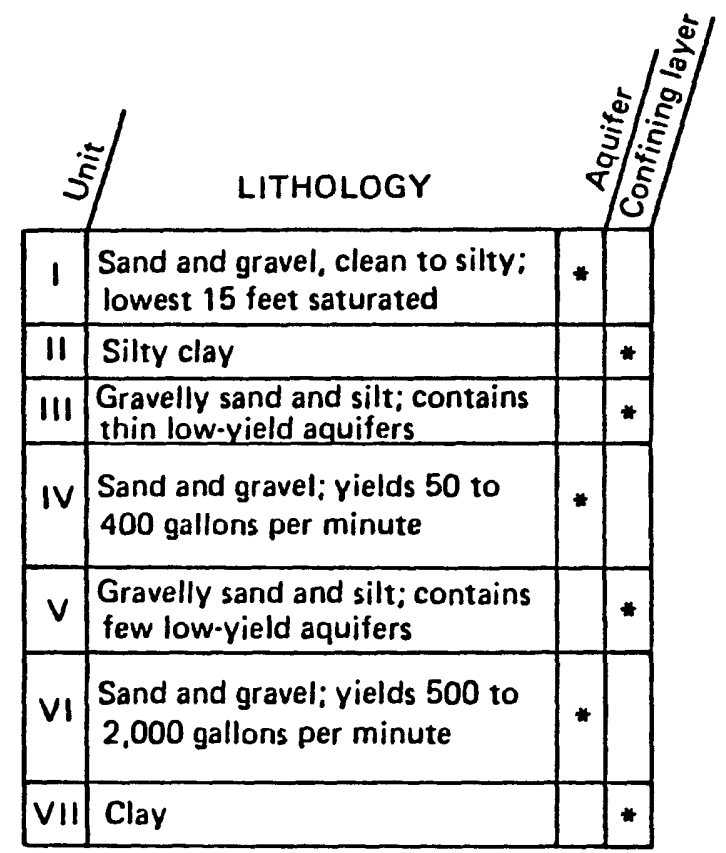

Figure 2.--Generalized stratigraphic column (Nelson, 1982).

\section{LANDFILL HISTORY}

The Merrill Field landfill was started by pushing accumulated refuse off the bluff near the east end of the Merrill Field Airport runway. In the early 1970's, the North Fork Chester Creek was diverted into a corrugated metal conduit through the middle of the landfill (fig. 1). The conduit, which is still in use, leaves the landfill just west of Sitka Street. From the outlet of the conduit, North Fork Chester Creek flows straight south in an open ditch to its junction with Chester Creek. Also in the early 1970's a leachate collection system (subdrain) was installed in the landfill at the top of a confining clay layer to intercept the leachate and discharge it into the sanitary sewer system. The subdrain routes the leachate to a lift station about $200 \mathrm{ft}$ east of the intersection of East 15th Avenue and Sitka Street, from which it is pumped into a concrete sanitary sewer line and eventually reaches the Point Woronzof Wastewater Treatment Facility. The landfill was closed in 1987. The surface will be seal coated to create more parking for small airplanes at Merrill Field Airport.

\section{ELECTROMAGNETIC SURVEY}

Electromagnetic (EM), or induction, techniques that measure ground conductivities can locate ground-water pollution from a landfill because salts that have been dissolved from the refuse give the ground water a higher capacity than uncontaminated ground water to conduct electricity (Evans, 1982; Kelly, 1976). Many investigations have been done using EM surveys to delineate contaminated plumes (Barlow and Ryan, 1985; Grady and Haeni, 1984; Greenhouse and Slaine, 1983; Mack and Maus, 1986). 
The Geonics ${ }^{1}$ EM34-3 used for this study consists of transmitter and receiver coils that are held coplanar (in the same plane) (Grantham and others, 1987). When the coils are held vertically, the instrument measures the ratio of the primary to secondary magnetic field generated by the horizontal dipole and, when held horizontally, the instrument measures the ratio of the primary to secondary magnetic field generated by the vertical dipole. The EM34-3 is calibrated to be a directreading, linear terrain-conductivity meter (McNeill, 1980a). The earth conductivity is measured in millisiemens per meter $(\mathrm{mS} / \mathrm{m})$.

Six data points are obtained at each sampling point by taking readings at both the vertical and horizontal coplanar orientations at three coil spacings (the distance between the transmitting coil and the receiving coil): $10-\mathrm{m}, 20-\mathrm{m}$, and $40-\mathrm{m}$. The exploration depth is dependent on the coil spacing and the operating frequency of the instrument (table 1 ).

Table 1.--Approximate exploration depths for EM34-3 at various intercoil spacings (McNeill 1980a)

$\begin{array}{ccc}\begin{array}{c}\text { Intercioil spacing } \\ \text { (meters) }\end{array} & \begin{array}{c}\text { Approximate expleration depth (meters) } \\ \text { Horizontal dipoles }\end{array} & \text { Vertical dipoles } \\ 10 & 7.5 & 15 \\ 20 & 15 & 30 \\ 40 & 30 & 60\end{array}$

For the direct surface electromagnetic reading to be a measure of the electrical conductance of ground water, the thickness of the unsaturated zone and subsurface lithology must be generally uniform, and no cultural sources of interference, such as power lines, pipelines, scrap metal storage, traffic, and metal fences should be present. Within the wetlands of the study area the unsaturated zone is 0 to $6.5 \mathrm{ft}$ thick, and minor lithologic differences were thought to be of little electromagnetic significance. However, potential sources of interference that could cause anomalies or scatter in the data are present. A power line and major roadway along the north side of the wetlands, sewer lines and condominiums on the east side, and homes and utility corridors along the west side appear to have affected the readings in the peripheral part of the study area. A power line through the middle of the wetlands had a minor local effect on the earth conductivity readings. To minimize interference from these cultural features, the sampling grid was oriented perpendicular to them, and to avoid any radio-frequency interference, readings were suspended when aircraft passed overhead.

1 Use of trade names in this report is for identification purposes only and does not constitute endorsement by the U.S. Geological Survey. 


\section{ELECTROMAGNETIC SURVEY RESULTS}

The EM surveys were made in the winter of 1986 when the surface water in the wetlands was frozen. Although the weather was cold and occasionally snowy, collecting the data under such conditions proved more efficient than trying to use the coils while standing in water. Each EM measurement station was located midway between the transmitting and receiving coil, and six data readings were taken at each of the 444 stations.

An EM survey was done along Chester Creek upstream from any influence of Merrill Field landfill to determine the "background" readings (those in areas of no contamination) for glacial materials such as those in the study area. The $10-\mathrm{m}$ coil spacing was used for this survey. The results of this survey indicate that background values are less than $4 \mathrm{mS} / \mathrm{m}$ (fig. 3 ). The one reading that exceeds $4 \mathrm{mS} / \mathrm{m}$ is close to Chester Creek and may be influenced by particles in the creek.

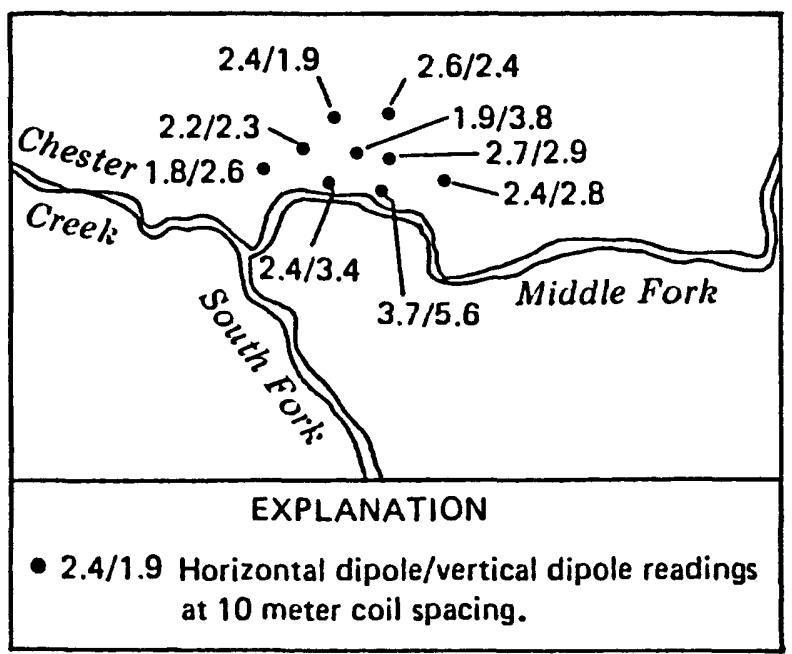

Figure 3.--Background values, apparent earth conductivity, in millisiemens per meter. (See figure 1 for location.)

A 100-foot sampling grid was surveyed throughout the northern part of the wetlands. When the EM measurements indicated ground conductivities substantially above background, the grid was extended to Chester Creek. All measuring points were surveyed to an approximate horizontal accuracy of $2 \mathrm{ft}$.

Data from the $10-\mathrm{m}$ coil spacing surveys of shallow soils show a relatively high conductivity zone beginning near the intersection of East 15th Avenue and Sitka Street, crossing the wetlands toward the southwest, joining the original North Fork Chester Creek channel along the western side of the wetlands, and approximately following this channel to Chester Creek (fig. 4). This pattern indicates that a concentrated plume of contaminants is present near the corner of Sitka Street and East 15th Avenue. The data in figure 4 also indicate that smaller amounts of contaminants have reached most of the wetlands. The $20-\mathrm{m}$ coil spacing data also show high readings in the area of Sitka Street and East 15th Avenue (fig. 5). However, many of these readings are only slightly above the background values. At the 40-m coil spacing, elevated readings of the horizontal dipole persist near the intersection of Sitka Street and East 15th Avenue. Readings are slightly elevated along the two roadways, but most readings are at background level (fig. 6). The progressive decrease in 


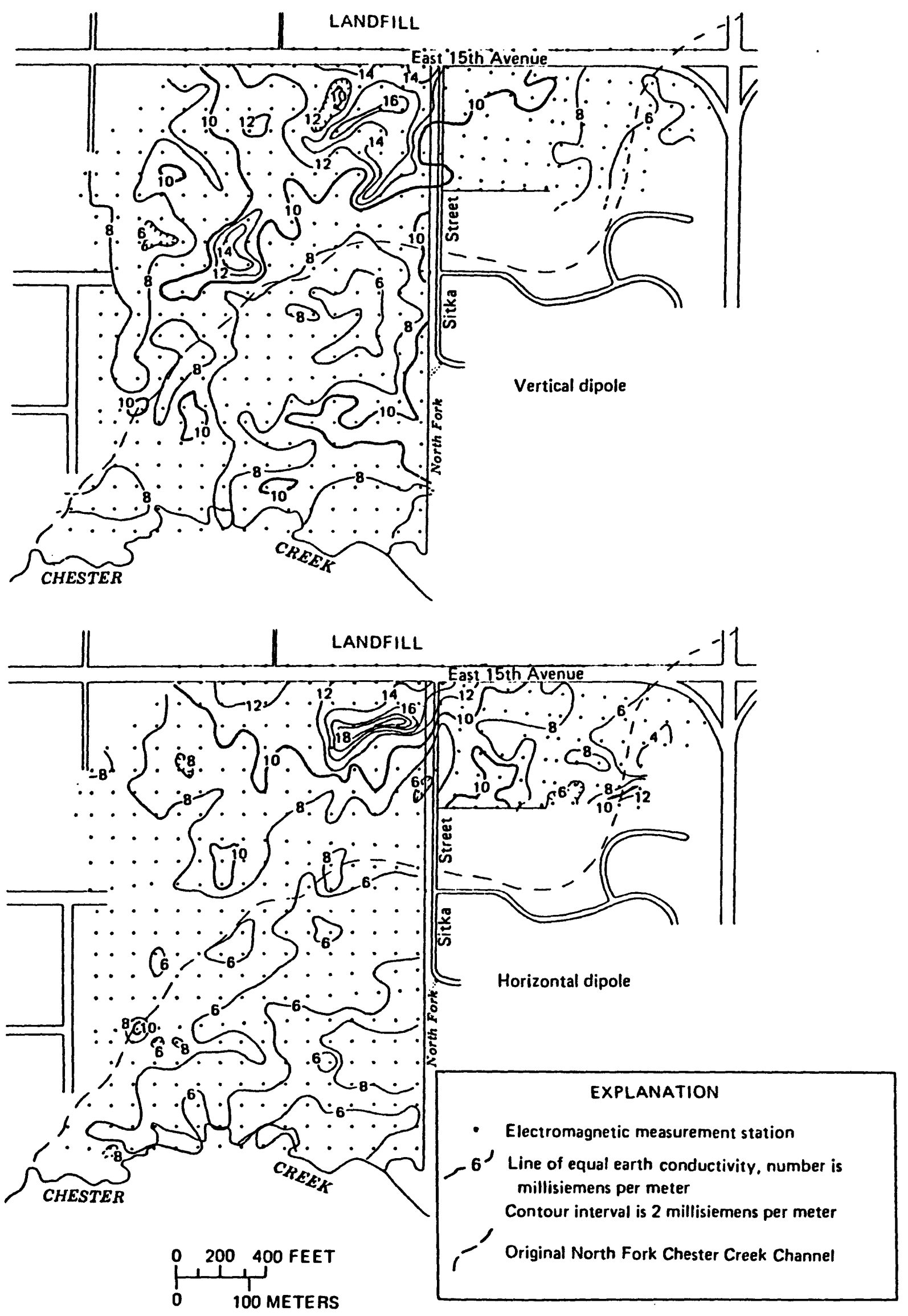

Figure 4.--Apparent earth conductivity, 10-meter coil spacing. (See figure 1 for location.) 


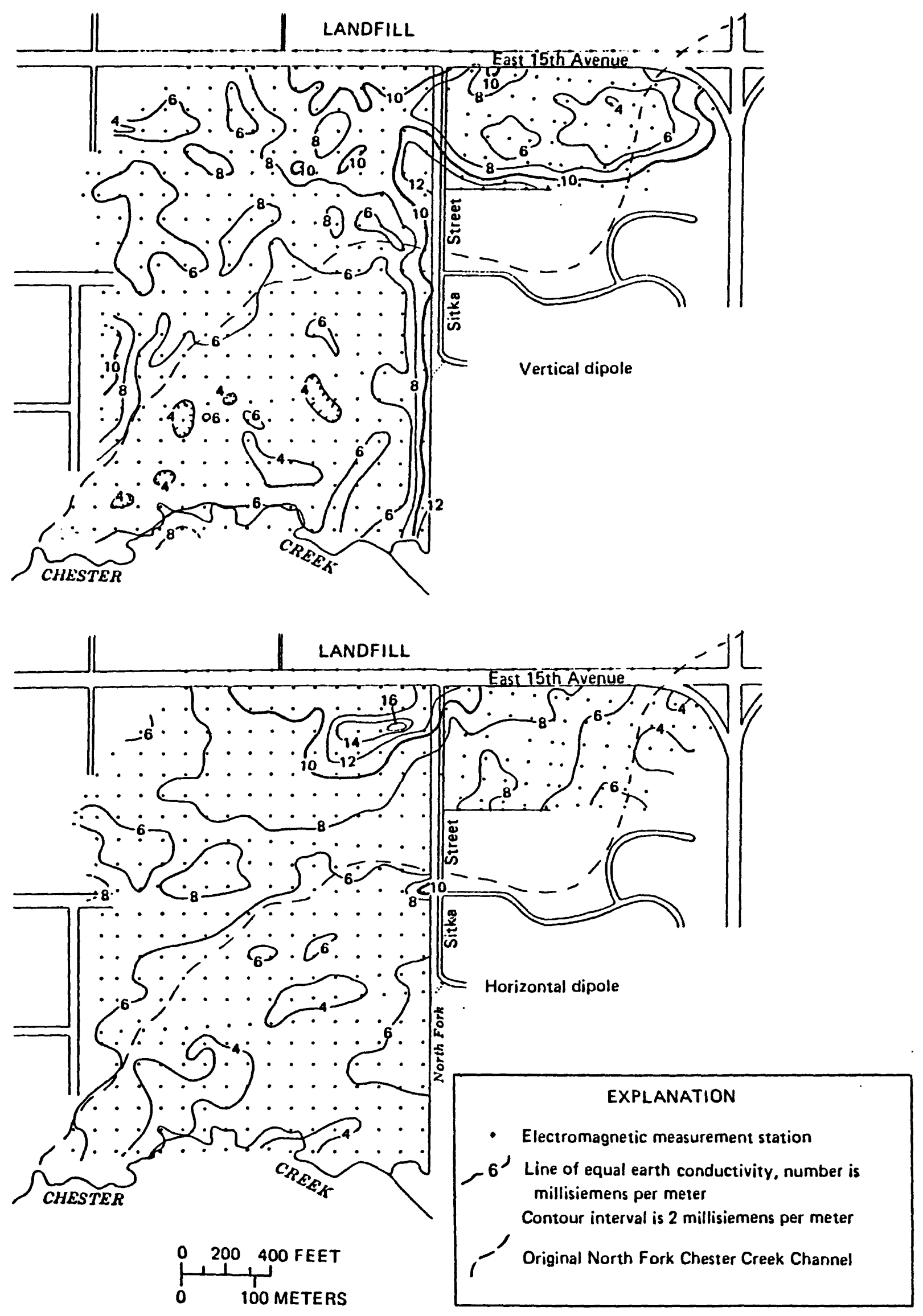

Figure 5.--Apparent earth conductivity, 20-meter coil spacing. (See figure 1 for location.) 

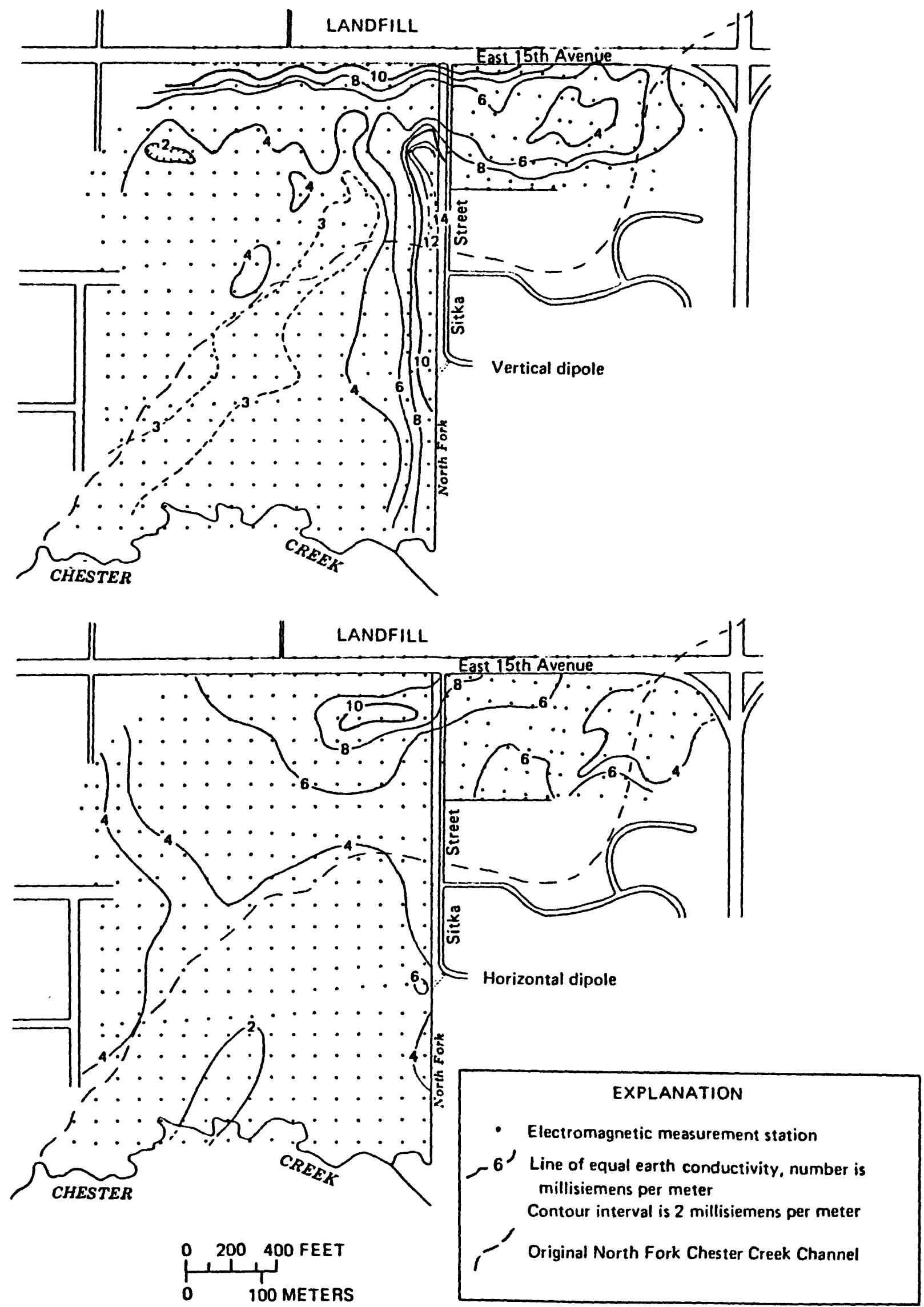

Figure 6.--Apparent earth conductivity, 40-meter coil spacing.

(See figure 1 for location.) 
measured EM conductivities with increasing exploration depth (greater coil spacing) indicates that the concentration of contaminants decreases with depth. Thus the contamination is present primarily in the shallow unconsolidated silty sand and gravel.

\section{OBSERVATION WELLS}

Water-level (table 2) and water-quality data from 20 observation wells (fig. 7) were analyzed in this study. Wells 1 to 5 and 8 to 12 were drilled either for other studies or to obtain preliminary data for this study prior to the electromagnetic survey. Observation wells 13 to 22 were drilled after the electromagnetic survey was completed and were generally sited where the survey indicated high conductivity values, i.e. where contamination was suspected (fig. 8). The survey proved valuable for selecting well sites to locate this plume. A generalized geologic section of the landfill (fig. 7) supports the assumptions made in the Electromagnetic Survey section, that the thickness of the unsaturated zone and the subsurface lithology are uniform.

\section{WATER-QUALITY RESULTS}

The specific conductance of ground water determined by analysis of samples from the observation wells correlated well with earth conductivity values obtained in the electromagnetic survey at the $10 \mathrm{-m}$ coil spacing (fig. 9). Readings at the $10 \mathrm{-m}$ spacing represent apparent earth conductivity of approximately the upper $50 \mathrm{ft}$ of subsurface materials.

Water-quality samples were collected and analyzed for all the priority pollutants, according to U.S. Environmental Protection Agency (EPA) (1987a) standards. In November and December 1985, samples were collected from observation wells 1 to 5 and 8 to 12; in August and September 1986, samples were collected from all wells. Table 3 shows chemical species that were detected and in which wells they were detected. Table 4 contains a listing of chemical species that were not detected in any of the samples, and table 5 lists wells in which concentrations exceeded drinking water standards (Alaska Dept. of Environmental Conservation, 1979; U.S. EPA 1977, 1987b). A complete listing of analyses is available on request from the U.S. Geological Survey.

Wells 3 and 12 in 1985, and wells 3,11 , and 12 in 1986 had water that contained high concentrations of organic (extractable and purgeable) compounds, trace metals, and common ions. Wells 3 and 12 were completed within the landfill material, so the higher concentrations were expected. In well 11, which was completed at a depth below the landfill material, contamination was not evident in 1985, but by 1986 the leachate apparently had migrated downward, possibly around the casing.

Wells 1,2 , and 4 are $90 \mathrm{ft}$ deep or deeper and are not affected by the leachate. This substantiates previous estimates (Nelson, 1982) that deep migration of pollutants will not be rapid.

No discernable patterns in concentrations of organic compounds and trace metals were evident in any of the other samples. However, a general decrease in specific conductance and chloride concentration is evident as distance from the landfill increases (fig. 10). The incidence of detectable organic contaminants also generally decreases toward Chester Creek (fig. 10). These trends may be due in part to sorption of pollutants on clays and silts common in the aquifer. As ground water 
Table 2.--Observation well information

\begin{tabular}{|c|c|c|c|c|c|c|}
\hline \multirow{3}{*}{$\begin{array}{l}\text { Well } \\
\text { No. } \\
\text { (fig. } \\
7 \text { ) } \\
1\end{array}$} & \multirow{3}{*}{$\begin{array}{c}\begin{array}{c}\text { Date } \\
\text { drilled }\end{array} \\
6 / 6 / 74\end{array}$} & \multirow{3}{*}{$\begin{array}{l}\text { Well } \\
\text { depth } \\
\text { (feet } \\
\text { below } \\
\text { land } \\
\text { surface) }\end{array}$} & \multicolumn{2}{|c|}{ Well completion } & \multirow{2}{*}{\multicolumn{2}{|c|}{ 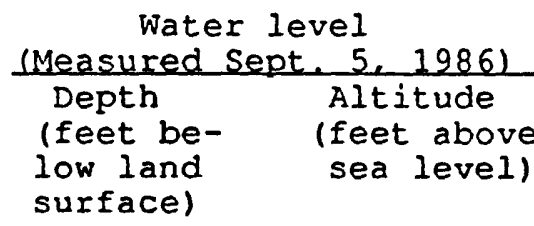 }} \\
\hline & & & $\begin{array}{l}\text { Well co } \\
\text { Type }\end{array}$ & $\begin{array}{l}\text { letion } \\
\text { Screened } \\
\text { interval } \\
\text { (feet) }\end{array}$ & & \\
\hline & & & Open end & -- & 40.5 & 81.15 \\
\hline 2 & $6 / 10 / 74$ & 90 & Open end & -- & 40.0 & 81.15 \\
\hline 3 & $6 / 11 / 74$ & 39 & Screened & $13-19$ & 28.3 & 92.79 \\
\hline 4 & $8 / 17 / 76$ & 91 & Open end & -- & 5.34 & 80.26 \\
\hline 5 & $8 / 28 / 76$ & 35 & Screened & $32-35$ & 5.48 & 80.56 \\
\hline 8 & $10 / 3 / 85$ & 20 & Screened & $9-19$ & 3.78 & 107.25 \\
\hline 9 & $10 / 3 / 85$ & 25 & Screened & $15-25$ & 3.70 & 71.80 \\
\hline 10 & $10 / 9 / 85$ & 45 & Screened & $25-45$ & 7.58 & 89.18 \\
\hline 11 & $10 / 1 / 85$ & 70 & Screened & $50-70$ & 38.38 & 90.79 \\
\hline 12 & $10 / 2 / 85$ & 50 & Screened & $29-49$ & 30.03 & 91.47 \\
\hline 13 & $9 / 2 / 86$ & 20 & Screened & $10-20$ & 6.78 & 79.95 \\
\hline 14 & $9 / 2 / 86$ & 20 & Screened & $10-20$ & 6.38 & 78.74 \\
\hline 15 & $9 / 3 / 86$ & 15 & Screened & $5-15$ & .63 & 77.94 \\
\hline 16 & $9 / 3 / 86$ & 20 & Screened & $10-20$ & .65 & 76.47 \\
\hline 17 & $9 / 3 / 86$ & 20 & Screened & $5-15$ & .64 & 76.28 \\
\hline 18 & $9 / 4 / 86$ & 15 & Screened & $5-15$ & .62 & 73.96 \\
\hline 19 & $9 / 4 / 86$ & 15 & Screened & $5-15$ & -.06 & 72.10 \\
\hline 20 & $9 / 4 / 86$ & 20 & Screened & $5-15$ & .56 & 70.66 \\
\hline 21 & $8 / 28 / 86$ & 21 & Screened & $11-21$ & .03 & 69.68 \\
\hline 22 & $8 / 28 / 86$ & 20 & Screened & $10-20$ & .21 & 71.84 \\
\hline
\end{tabular}




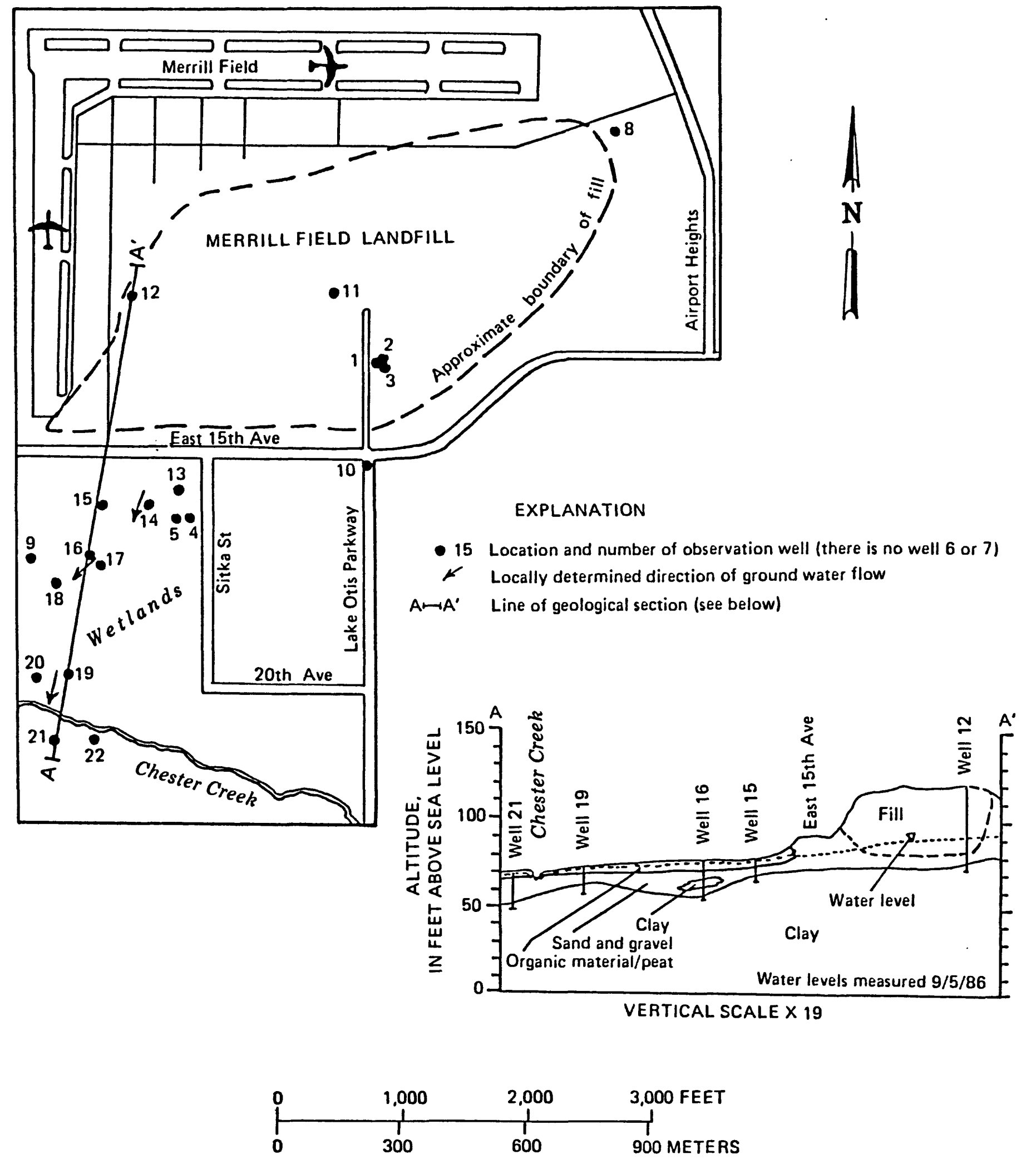

Figure 7.--Locations of observation wells, and geologic section through wetlands and the landfill. (See figure 1 for location.) 


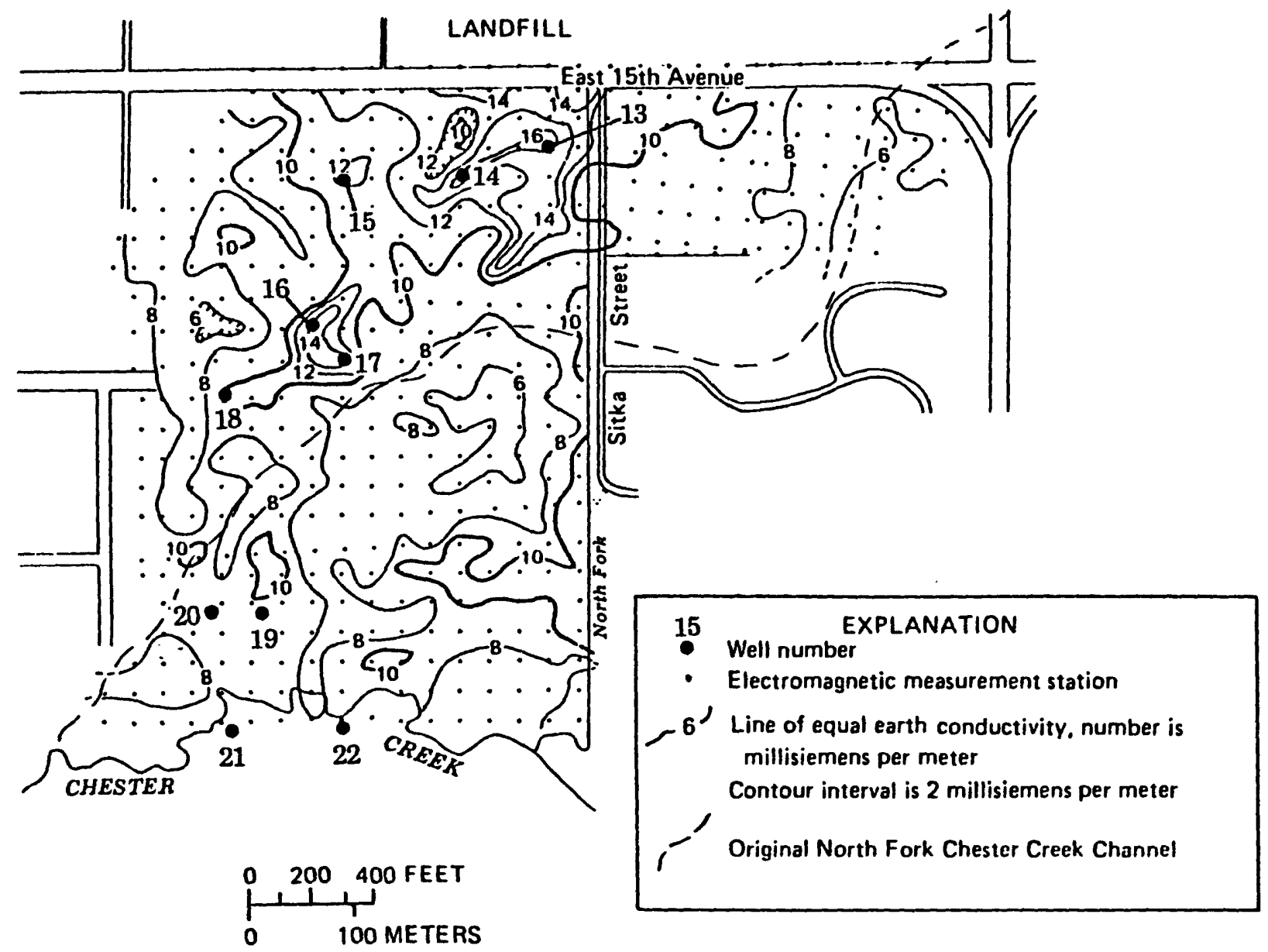

Figure 8.--Location of wells 13-22 sited in areas of high conductivity.

(See figure 1 for location.) 


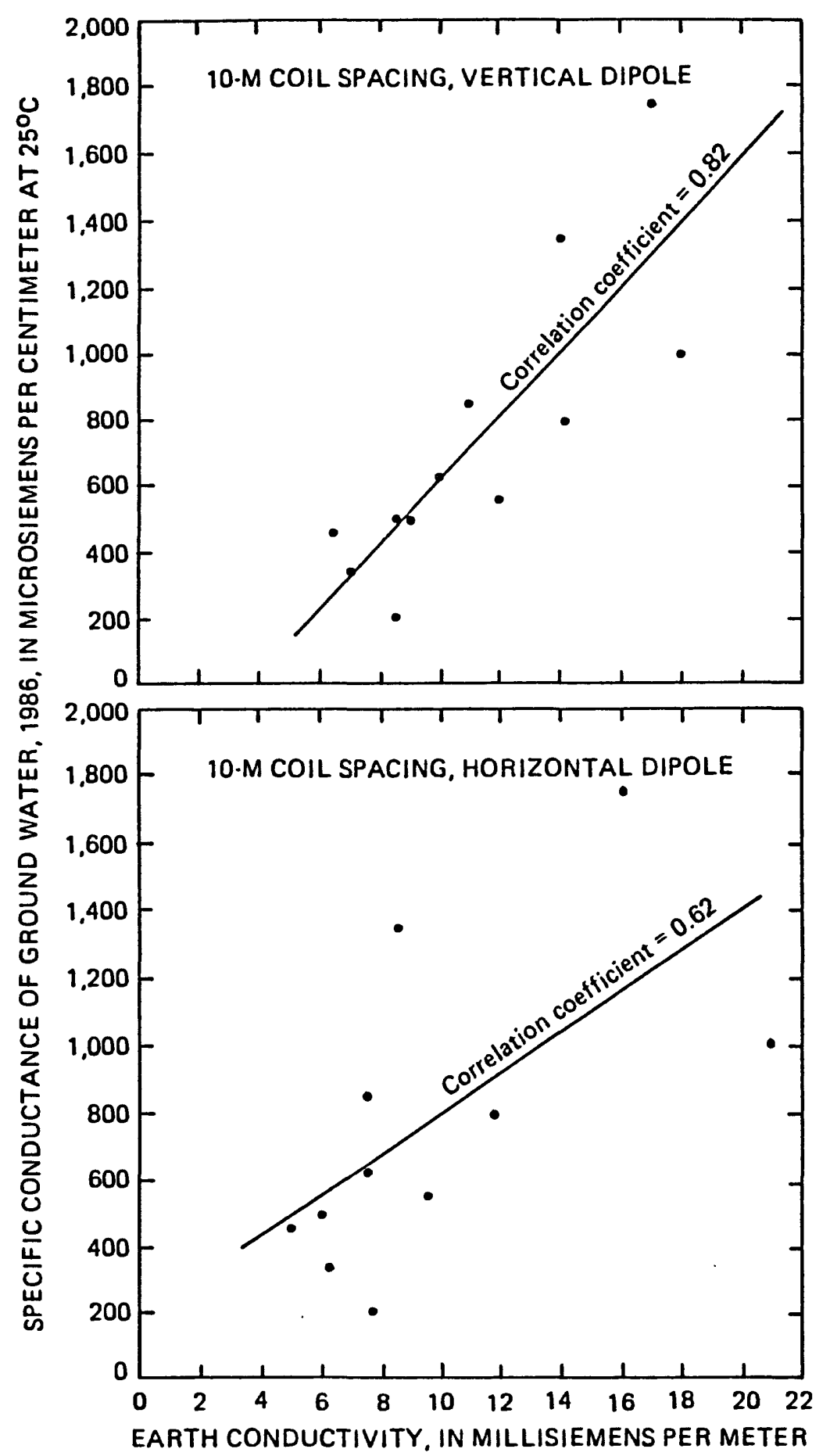

Figure 9.--Relation between earth conductivity and specific conductance of ground water. 
Table 3.--Chemicals detected in ground-water samples

[Values not in data base; $\mu \mathrm{g} / \mathrm{L}$, microgram per liter]

\begin{tabular}{|c|c|c|}
\hline Constituent & Wells in which found & $\begin{array}{c}\text { Maximum } \\
\text { concentration } \\
(\mu \mathrm{g} / \mathrm{L})\end{array}$ \\
\hline $\begin{array}{l}\text { Benzene } \\
\text { bis (2-Ethylhexyl) phthalate } \\
\text { Carbon tetrachloride } \\
\text { Chloroethane } \\
\text { Chloroform } \\
\text { Chloromethane } \\
\text { Dichlorodifluoromethane } \\
\text { Diethyl phthalate } \\
\text { Ethylbenzene } \\
\text { Ereon } \\
\text { Methyl chloride } \\
\text { Methylene-chloride } \\
\text { Tetrachloroethylene } \\
\text { Toluene } \\
\text { Trichloroethylene } \\
\text { Trichlorofluoromethane } \\
\text { Vinyl chloride } \\
\text { Xylenes } \\
\text { 1,1-Dichloroethane } \\
\text { 1,1,1-Trichloroethane } \\
1,2-D i c h l o r o e t h a n e \\
1,2-D i c h l o r o p r o p a n e \\
\text { 1,2-trans-Dichloroethylene } \\
\text { 2,4-Dimethylphenol }\end{array}$ & $\begin{array}{l}2 \star, 3,11,12,13,15,21,22 \\
2,11 \\
4 \\
2 \star, 3,11,12,14 \\
4,12,13,14,21 \\
12 \\
4,5,9,11,12,14,15,16,17 \\
3 \\
3,12 \\
12 \\
11,12,14,16,17,18 \\
1 \star, 2,3,4,5 \star, 9 \star, 10 \star, 11,12 \\
12 \\
3,4,5,12,14 \\
3,4,12 \\
4,12 \\
2,3,5,11,12,14 \\
3,12 \\
5,12 \\
12,16 \\
3,11,12 \\
3 \\
3,12 \\
3\end{array}$ & $\begin{array}{c}20 \\
65 \\
0.2 \\
33 \\
0.6 \\
20 \\
90 \\
42 \\
4.8 \\
8.2 \\
17 \\
320 \\
6.9 \\
560 \\
8.0 \\
4.5 \\
53 \\
41 \\
140 \\
26 \\
1.5 \\
0.5 \\
8.8 \\
6\end{array}$ \\
\hline $\begin{array}{l}\text { Antimony, total } \\
\text { Arsenic, total } \\
\text { Cadmium, total } \\
\text { Chromium, total } \\
\text { Copper, total } \\
\text { Iron, total } \\
\text { Lead, total } \\
\text { Manganese, total } \\
\text { Mercury, total } \\
\text { Nickel, total } \\
\text { Silver, total } \\
\text { Zinc, total }\end{array}$ & $\begin{array}{l}1,2,3,4,5,8,9,10,11,12,15,17,22 \\
\text { Ail } \\
11,19 \\
\text { Al1 } \\
\text { All } \\
\text { All } \\
1,2,3,4,8,9,10,11,12,17,18,22 \\
\text { All } \\
1,8,9,10,11,12,14,15,17,19,20 \\
\text { Al1 } \\
10 \\
\text { All, except } 20\end{array}$ & $\begin{array}{r}14 \\
130 \\
1 \\
350 \\
1,100 \\
500,000 \\
300 \\
84,000 \\
1.1 \\
1,000 \\
1 \\
3,500\end{array}$ \\
\hline
\end{tabular}

*Trace occurrences based on laboratory rerun 
Table 4.--Chemicals analyzed but not detected in any samples

BASE/NEUTRAL EXTRACTABLE COMPOUNDS

\section{Acenaphthene}

Acenaphthylene

Anthracene

Benzo(a) anthracene 1,2-benzoanthracene

Benzo (a) pyrene

Benzo (b) fluoranthene

Benzo $(g, h, i)$ perylene $1,1,2$-benzoperylene

Benzo (k) fluoranthene

bis (2-Chloroethoxy) methane

bis 2-Chloroethyl ether

bis (2-Chloroisopropyl) ether

Chrysene

Di-n-butyl phthalate

Di-n-octylphthalate,

Dimethyl phthalate

Fluoranthène

Fluorene

Hexachlorobenzene

Hexachlorobutadiene

Hexachlorocyclopentadiene

Hexachloroethane

Indeno $(1,2,3-c d)$ pyrene

Isophorone

n-Nitrosodimethylamine

n-Nitrosodi-n-propylamine

n-Nitrosodiphenylamine

Naphthalene

Nitrobenzene

Phenanthrene

Pyrene

1,2-Dichlorobenzene

$1,2,4-T r i c h l o r o b e n z e n e$

$1,2,5,6-$ Dibenzanthracene

1,3-Dichlorobenzene

1,4-Dichlorobenzene

2-Chloronaphthalene

$2,3,7,8-$ Tetrachlorodibenzo-p-dioxin

2, 4-Dinitrotoluene

2,6-Dinitrotoluene,

4-Bromophenyl phenyl ether

4-Chlorophenyl phenyl ether
PURGEABLE ORGANIC COMPOUNDS

(Volatile compounds)

Bromoform

Chlorobenzene

Chlorodibromomethane

cis-1,3-Dichloropropene

Dichlorobromomethane

Methyl-bromide

Styrene

trans-1, 3-Dichloropropene

1,1-Dichloroethylene

$1,1,2-$-Chloroet hane

1,1,2-Trichloroethane

$1,1,2,2$-Tet rachloroethane

1,2-Dibromoethylene

1,2-Di-chlorobenzene

1,3-Di-chlorobenzene

1,3-Dichloropropene

1, 4-Di-chlorobenzene

2-Chloroethylvinylether

ACID-EXTRACTABLE COMPOUNDS

Parachlorometa cresol (also

known as chloro-methylphenol)

Pentachlorophenol

Phenol

2-Chlorophenol

2-Nitrophenol

2,4-Dichlorophenol

2, 4-Dinitrophenol

2, 4, 6-Trichlorophenol

4-Nitrophenol

4,6-Dinitro-orthocresol (also

known as Dinitromethylphenol)

TRACE METALS

Beryllium, total

Cyanide, total

Selenium, total

Thallium, total 
Table 5.--Wells in which concentrations exceeded drinking-water standards

$[\mu \mathrm{g} / \mathrm{L}$, microgram per liter]

Constituent Wells in which found

Drinking-water standard maximum concentration limit $(\mu \mathrm{g} / \mathrm{L})$

\begin{tabular}{llc}
\hline Benzene & 3,12 & 5.0 \\
Trichloroethylene & 12 & 5.0 \\
Vinyl chloride & $3,11,12,14$ & 1.0 \\
Arsenic, total & $1,2,5$ & 50 \\
Chromium, total & 8,9 & 50 \\
Iron, total & All, except $1,4,21$ & 3,000 \\
Lead, total & $3,10,11,22$ & 50 \\
Manganese, total & All & 50 \\
Nickel, total & $8,9,10,11,12,15,17,18,22$ & 13.4 \\
Zinc, total & $10,11,12$ & 320 \\
\hline
\end{tabular}



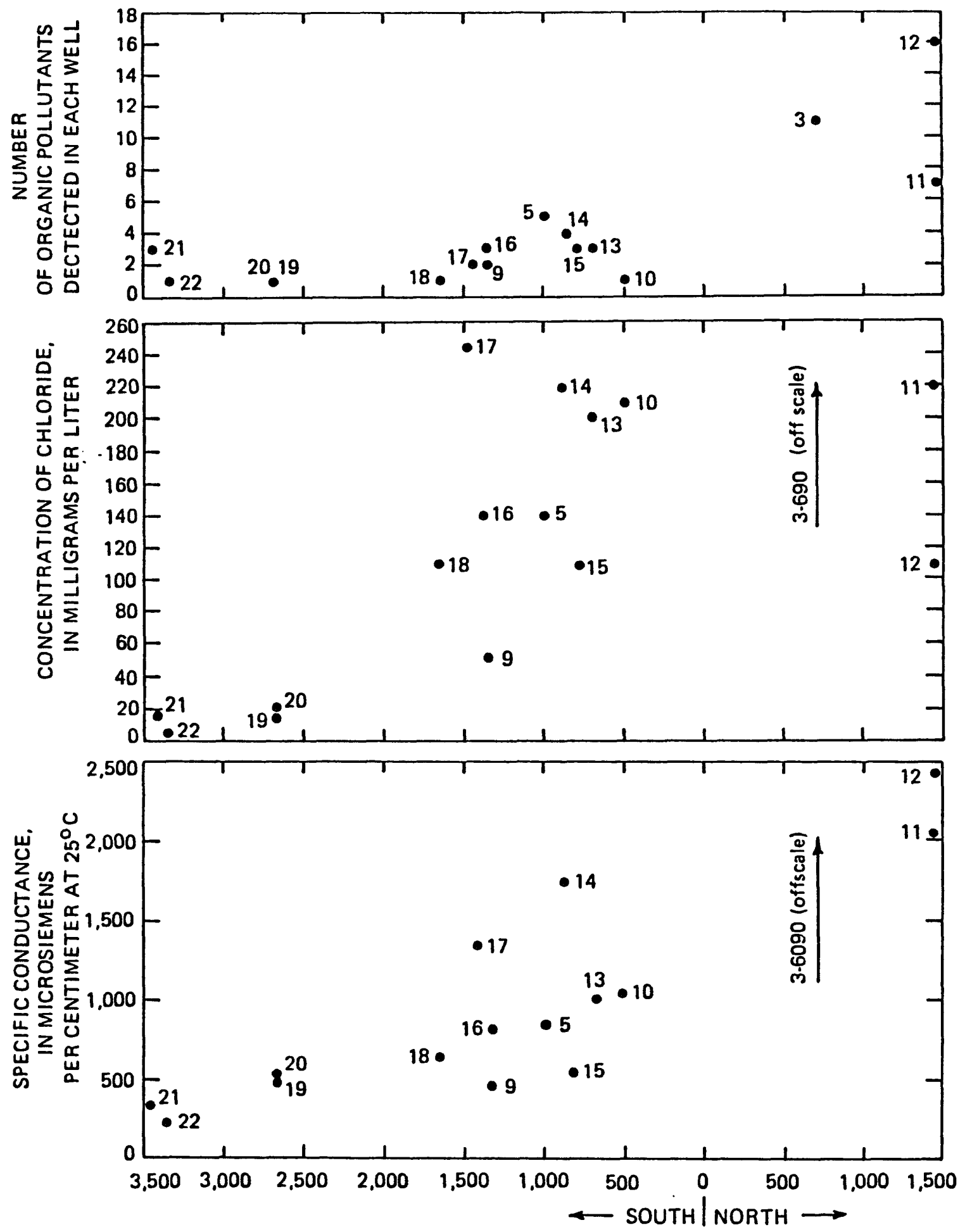

DISTANCE FROM SOUTH EDGE OF LANDFILL, IN FEET

EXPLANATION : $\bullet 14$ Well number

Figure 10..-Changes in specific conductance, concentration of chloride, and number of organic pollutants detected in each well with increasing distance from the landfill. 
continues to carry leachate through the aquifer and sorption sites on the clays become saturated, the concentrations of ions in ground water may increase.

During these initial two rounds of sampling, the wells were pumped long enough to void at least three casing volumes of water prior to taking the actual sample. Monitoring specific conductance throughout the pumping period to ensure that it stabilized served as a check that the water being sampled was representative of the aquifer. To make sure that the volatile organic compounds were not being lost by this technique, wells 13 to 22 were sampled twice in June 1987, once prior to pumping and then again after pumping. In most cases the concentrations of the volatiles were higher after pumping. In the few cases where the reverse was true, the differences in concentrations were so slight that they could have been attributable to normal analytical error.

North Fork Chester Creek does not appear to undergo significant contamination during its transit through the conduit buried in the landfill, but limited evidence suggests that a small amount of leachate may be entering the creek through leaks in the conduit. Trace amounts of six organic compounds, only one of which is present in the creek above the landfill, were detected in samples from the conduit outlet (table 6). The concentrations of iron and manganese, both of which are present in high concentrations in leachate, also increase substantially as the creek flows through the landfill. However, concentrations of sodium and chloride, which are highly concentrated in leachate, do not increase substantially. In fact, in the samples collected in August 1986, the concentrations of both sodium and chloride were lower downstream from the landfill.

\section{Table 6.--Selected chemical constituents of North Fork Chester Creek above and below the landfill}

[ND, not detected; $T$, trace; $\mu \mathrm{g} / \mathrm{L}$, microgram per liter; $\mathrm{mg} / \mathrm{L}$, milligram per liter. Complete analyses are available on request from the

U.S. Geological Survey.]

\begin{tabular}{|c|c|c|c|c|}
\hline \multirow[b]{2}{*}{ Constituent } & \multicolumn{2}{|c|}{ December 2,1985} & \multicolumn{2}{|c|}{ August 27,1986} \\
\hline & Above & Below & Above & Below \\
\hline Dichlorodifluoromethane $(\mu \mathrm{g} / \mathrm{L})$ & ND & ND & 0.4 & 0.5 \\
\hline Tetrachloroethylene $(\mu \mathrm{g} / \mathrm{L})$ & ND & $\mathrm{T}$ & ND & .2 \\
\hline Toluene $(\mu g / L)$ & ND & 5.0 & ND & ND \\
\hline Trichloroethylene $(\mu \mathrm{g} / \mathrm{L})$ & ND & ND & ND & .2 \\
\hline Vinyl Chloride $(\mu \mathrm{g} / \mathrm{L})$ & ND & ND & ND & .2 \\
\hline 1,1 -Dichloroethane $(\mu \mathrm{g} / \mathrm{L})$ & ND & ND & ND & .2 \\
\hline $\begin{array}{l}\text { Chloride, dissolved (mg/L) } \\
\text { Iron, dissolved }(\mu \mathrm{g} / \mathrm{I})\end{array}$ & $\begin{array}{r}41 \\
370\end{array}$ & $\begin{array}{r}45 \\
5,800\end{array}$ & $\begin{array}{r}25 \\
160\end{array}$ & $\begin{array}{r}19 \\
300\end{array}$ \\
\hline Manganese, dissolved $(\mu \mathrm{g} / \mathrm{L})$ & 46 & $\begin{aligned} 240 \\
240\end{aligned}$ & 41 & 170 \\
\hline Sodium, dissolved (mg/L) & 11 & 15 & 8.9 & 8.3 \\
\hline
\end{tabular}




\section{CONCLUSIONS}

1. Ground water in the wetlands south of Merrill Field landfill is flowing toward the southwest, transporting contaminants toward Chester Creek, but the concentrations of these contaminants in the ground water are generally below the EPA standards for drinking water.

2. Both the electromagnetic survey of shallow subsurface geologic materials and analyses of groundwater samples indicate that the contaminants are concentrated in the upper $50 \mathrm{ft}$ of the surface. The correlation between specific conductance of ground water and earth conductivity permits use of such surveys to estimate the extent of migration of landfill contaminants. The survey indicates that small amounts of pollutants probably have reached most of the wetlands and a slightly more concentrated plume of contaminants is present near the corner of Sitka Street and East 15th Avenue.

3. The electromagnetic survey is a valuable tool for designing a drilling program to sample points where the contamination was greatest. The location of the most concentrated plume of contaminants would not have been apparent and probably would have been missed without the EM survey. data.

4. In the wetlands, the unconfined aquifer is generally less than $30 \mathrm{ft}$ thick and is underlain by a poorly permeable silty clay that inhibits the vertical migration of water. Therefore, any contamination from Merrill Field landfill will be expected to move laterally through the unconfined aquifer toward Chester Creek.

5. Analyses for volatile organic compounds generally indicated higher concentrations when the wells were pumped before sampling than when samples were collected without pumping.

6. The water of North Fork Chester Creek is not significantly affected by its transit through the enclosed conduit in the landfill, but minor amounts of leachate may be entering the creek.

\section{REFERENCES CITED}

Alaska Department of Environmental Conservation, 1979, Water quality standards: Alaska Department of Environmental Conservation, Alaska Water Pollution Control Program, 34 p.

Barlow, P.M., and Ryan, B.J., 1985, An electromagnetic method for delineating ground-water contamination, Wood River Junction, Rhode Island, in Subitsky, Seymour, ed., Selected papers in the hydrologic sciences: U.S. Geological Survey Water-Supply Paper 2270, p. 35-46.

Evans, R.B, 1982, Currently available geophysical methods for use in hazardous waste site investigations: American Chemical Society Symposium Series, no. 204, p. 93-115.

Grady, S.J., and Haeni, F.P., 1984, Application of electromagnetic techniques in determining distribution and extent of ground water contamination at a sanitary landfill, Farmington, Connecticut: Proceedings of the National Water Well Association/U.S. Environmental Protection Agency Conference on Surface and Borehole Geophysical Methods in Ground Water Investigations, p. 338-367. 
Grantham, D.G., Ellefsen, K., and Haeni, F.P., 1987, Forward-modelling computer program for the inductive electromagnetic ground-conductivity method--EM34.FOR: U.S. Geological Survey Open-File Report 87-213-A, 43 p.

Greenhouse, J.P., and Slaine, D.D., 1983, The use of reconnaissance electromagnetic methods to map contaminant migration: Ground Water Monitoring Review, v. 3, no. 2, p. 47-59.

Kelly, W.E., 1976, Geoelectric sounding for delineating ground-water contamination: Ground Water, v. 14 , no. 1 , p. $6-10$.

Mack, T.J., and Maus, P.E., 1986, Detection of contaminant plumes in ground water of Long Island, New York, by electromagnetic terrain-conductivity surveys: U.S. Geological Survey WaterResources Investigations Report 86-4045, 39 p.

McNeill, J.D., 1980a, Electromagnetic terrain conductivity measurement at low induction numbers: Mississauga, Ontario, Canada, Geonics Limited Technical Note TN-6, 15 p.

$1980 \mathrm{~b}$, Electrical conductivity of soils and rocks: Mississauga, Ontario, Canada, Geonics Limited Technical Note TN-5, 22 p.

Nelson, G.L., 1982, Vertical movement of ground water under the Merrill Field Landfill, Anchorage, Alaska: U.S. Geological Survey Open-File Report 82-1016, 24 p.

U.S. Environmental Protection Agency, 1977, Quality criteria for water, 1976. U.S. Government Printing Office, $256 \mathrm{p}$.

1987a, Guidelines establishing test procedures for the analysis of pollutants: U.S. Code of Federal Regulations, Title 40, Part 136, revised as of July 1, 1987.

1987b, National primary drinking water regulations: Synthetic organic chemicals--Monitoring for unregulated contaminants: U.S. Code of Federal Regulations, Title 40, Parts 141 and 142, revised as of July 8, 1987. 